\title{
CARBON NEUTRAL ENVIRONMENT FOR SUSTAINABLITY: A CASE STUDY OF AMC ENGINEERING COLLEGE
}

\author{
Jayashree Mani ${ }^{1}$, Mohiyuddin $\mathrm{C} \mathrm{S}^{2}$, Umashanker $\mathrm{L}^{3}$, Shashishankar $\mathrm{A}^{\mathbf{4}}$ \\ ${ }^{1} B E$ Student, Department of Civil Engineering, AMCEC \\ ${ }^{2}$ Assistant Professor, Department of Civil Engineering, AMCEC \\ ${ }^{3}$ Associate Professor, Department of Mechanical Engineering, AMCEC \\ ${ }^{4}$ Professor and Head, Department of Civil Engineering, AMCEC
}

\begin{abstract}
Purpose - The objective of this case study is to provide researched information about retrospect and prospect of achieving sustainable campus at AMC Engineering College (AMCEC) to reduce its carbon footprint and to establish a campus culture focused on the theme of environmental sustainability. Also parallely make available the solutions to globally similar institutions in achieving low carbon footprint.

Annually built environment releases billions of tons of carbon dioxide( CO2) which causes glassy layer in presence of Suspended Particulate Matter(SPM) at the outer atmosphere. This prevents the release of heat and reverts it back causing Green house effect. Lifestyle changes contribute to carbon footprint and hence a deviation in strategy such as use of Zero Energy Materials (ZEM) would mitigate ill effects. The recent theme is carbon neutral campuses which is incorporated in the accreditation process of National Assessment and Accreditation Council (NAAC) of University Grants Commission (UGC) and also National Board of Accreditation( NBA) under All India Council for Technical Education (AICTE).

The functionality of University affiliated colleges is hinged on Education and $R \& D$ towards reaching the micro economic societal requirements. This paper establishes the betterment of a 52 acre large campus towards holistic ecosystem having been located 6 kms from the famous Bannergatta National Park, achieving the desired goal of solutions through horizontal and vertical approach.
\end{abstract}

Keywords- Carbon footprint(CFP), Suspended Particulate Matter(SPM), Green house effect, Zero Energy Materials (ZEM), Colleges, NAAC,NBA, Case study. - ***

\section{PROLOGUE}

Climate change crisis is a global environmental and societal afflicting the planet. Paris Declaration has been signed in 2016 by all serious countries committed to consensus both on the basic science behind climate change (i.e., its causes and mechanism) and on a broad range of future climate projections coming from the modelling efforts.

The main reason for climate change is heat-trapping gases, also called green house gases(GHG), a major portion of which is caused by human activity due to fossil fuel burning activity on which the world energy demand is met with. Other emissions such as methane and nitrous oxide in smaller proportions come from carbon changes ( such as deforestation), agricultural activities, industrial processes, and waste management. Carbon dioxide is less offensive but comprises the majority of GHG emissions, at about $77 \%$ of the worldwide total. The remainder comes mostly from methane $\left(\mathrm{CH}_{4}\right)$ and nitrous oxide $(\mathrm{N} 2 \mathrm{O})$, with micro shares coming from fluorinated gases $\left(\mathrm{SF}_{6}, \mathrm{PFCs}\right.$, and HFCs). Global climate change has the potential to alter the earth's average temperature, raise sea levels, and shift entire ecosystem zones to an extent not seen since periods of glacial transformation, which in turn undoubtedly will severely affect human well-being and cause massive species extinctions.

Small number of countries, including United States, produce a large majority of global GHG emissions. In 2000, the U.S was the higest total GHG emitter ( contributing $20.6 \%$ of world's total emissions at 6,928 million metric tonnes of carbon daioxide equivalent), followed by China(14.7\%), EU(14.7\%),India(6\%) and others.

\section{CFP CONTRIBUTION PER YEAR}

\subsection{Carbon Foot Print (CFP) based on Embodied}

Energy of Construction Activity

\begin{tabular}{|c|c|c|}
\hline \multicolumn{3}{|c|}{ Table 1} \\
\hline $\mathrm{Sl} \mathrm{NO}$ & Description & Embodied Energy \\
\hline 1 & $\begin{array}{l}\text { Embodied energy for super } \\
\text { built up area }\end{array}$ & $450 \mathrm{MJ}$ per $\mathrm{m} 2$ \\
\hline 2 & Total super built up area & $59199.09 \mathrm{~m} 2$ \\
\hline 3 & Total energy & $26.64 \times 10^{6} \mathrm{MJ}$ \\
\hline
\end{tabular}


CO2 DUE TO EMBODIED ENERGY = EMBODIED ENERGY X $1.06 \mathrm{KG}$ OF CO2

$\begin{aligned} & =26.64 \times 106 \times 1.06 \\ & =28.24 \times 106 \mathrm{KG} \\ & =28.24 \times 103 \mathrm{TONS} \\ & =28240 \text { TONS OF CO2 } \\ \text { NO OF YEARS AMCEC EXISTED } & =17 \text { YEARS } \\ & =28240 / 17 \\ & =1661.17 \text { TONS OF CO2 }\end{aligned}$

\subsection{CFP based on Electricity Consumption}

Electricity consumed per month $=156 \mathrm{KWhr}$

Therefore for 12 months energy consumed $=156$ X 12 X 43

$=80.496 \mathrm{~kg}$ of $\mathrm{CO}_{2}$ per year

Calculation of $\mathrm{CO}_{2}$ emissions:

Table 2

\begin{tabular}{|l|l|}
\hline Fuel type & $\mathrm{Kg}$ of $\mathrm{CO}_{2}$ per unit consumption \\
\hline Grid Electricity & $43 \mathrm{Kg}$ per KWhr \\
\hline Natural gas & $3142 \mathrm{Kg}$ per tons \\
\hline Diesel fuel & $2.68 \mathrm{Kg}$ per liter \\
\hline Petrol & $2.31 \mathrm{Kg}$ per liter \\
\hline Coal & $2419 \mathrm{Kg}$ per tons \\
\hline LPG & $1.51 \quad \mathrm{Kg}$ per liter \\
\hline
\end{tabular}

\subsection{CFP due to Culinary Consumption (LPG)}

CFP due to Culinary Consumption (LPG)

X 4 X 12 X 1.51/1000

$=1.014$ tons of $\mathrm{CO} 2$ per $\mathrm{kg}$

DATA:

1 Cylinder $=14 \mathrm{~kg}$ of gas

4 Cylinders.

\subsection{CFP due to Diesel Generators for 82.5 KV and}

\section{KW Generators}

CFP due to Diesel Generators for $82.5 \mathrm{KV}$ and $125 \mathrm{KW}$ Generators $=1500 \times 12 \times 2.68 / 100=48.24$ tons of $\mathrm{CO}_{2}$

Generators Diesel per month $=15001 \mathrm{t}$

(82.5 KV \& $125 \mathrm{KV})$

2.68 is hour conversion factor

\subsection{CFP due to Transportation}

The transportation department deals with removal of obsolete low performance vehicles by the replacing with more fuel efficient options.

\section{Refer Table 3 for Details.}

CFP due to Transportation $=146.81$ tons of $\mathrm{CO} 2$

Total CFP Contribution CO2 per year

$=1937.72$ tons of $\mathrm{CO}_{2}$ Emission

\section{5 $\mathrm{CO}_{2}$ Neutrality in Tons due to Green Initiative}

\subsubsection{Hexagonal Best Practices Model at AMCEC}

1. Use of zero energy materials

2.Hybrid Wind and Solar Energy developed by National Aerospace Laboratory(NAL).

3.Use of recycled tertiary treated waste water.

4.Vermi Composting

5.Ecosystem modification and greening of campus.

6 . Rain water harvesting system.

\subsubsection{Use of Zero Energy Materials}

Alternative sands such as processed slag sand from Oblapuram, M Sand from Peresandra, Quary dust from near by Bannnergattta equivalent to Zone II river sand are being deployed for sustainability.Sintered FlyAsh Aggregates, Construction and Demolition waste replace a part of granitic coarse aggregates.Alternative Cementitious Materials such as Ground Granulated Blast Furnace Slag from JSW,Class C and Class F FlyAsh from Neyveli and Raichur Thermal Powerplants are used either in total or as partial replacement and deployed as Geo Polymer vis a vis research programmes at the Centre for Global Environment and Ecofriendly Technology Applications (C-GEETA)

\subsubsection{Carbon Neutrality due to 1 KW Hybrid NAL Wind Solar Station $4500 \mathrm{Kg}$}

National Aerospace laboratory has collaborated with the solar energy club at AMCEC and an initial demonstration project on top of 5th floor of Civil Engineering Department is recently commissioned to utilize green energy for the cutter pumps provided at the equalization tank of fixed film bioreactor. This is unique because integration of both solar and wind energy gives a hybrid approach.

Carbon neutrality due to $1 \mathrm{KW}$ hybrid NAL wind solar station $4500 \mathrm{Kg}=2500 \times 43=107500 \mathrm{~kg}$ of $\mathrm{CO} 2$ neutralized

$=107.5$ tons of $\mathrm{CO} 2$ neutralized per year

Data: 250 working days per year

10 hours of working per day $=2500 \mathrm{KWhr}$

\subsubsection{Sewage Treatment Plant (STP)}

Sequential planted canna bio reactor using three types of patented bacteria convert a septic tank effluent into useable water for vegetation and cricket stadium, lawns etc. The quality is compatible to urban recycle standards as per Karnataka state pollution control board norms (Biochemical Oxygen Demand BOD less than $10 \mathrm{mg} / \mathrm{l}$ and Total Suspended Solids TSS less than $10 \mathrm{mg} / \mathrm{l}$ )

$$
\begin{aligned}
\text { Water pumped per day } & =55000 \text { lts per day } \\
& =55000 \times 180(\text { working days }) \\
& =9.9 \times 106 \mathrm{lts}
\end{aligned}
$$


Waste water generated $=80 \%$ of water supply $=0.8 \times 9.9 \times 106$

$=7.92 \times 106$ lts per year

$=7.920$ X103 KLD per year

Waste Water recycled $=7920$ KLD per year

Zero Discharge Technology

$20 \%$ of electricity consumed is for pumping $=0.20 \mathrm{X}$

$80.496=16.09$ tons of $\mathrm{CO} 2$ per year neutralized

\subsubsection{Green Initiative due to Vermicomposting}

It is a shallow rectangular plot with sufficient aeration for mega scolex maurity. The worms devour the organic leafy materials and excrete simple harmless substances called humus which is very high in NPK value.

A plot of $2.14 \times 0.92 \times 0.56$

For 10 numbers of plots $\mathrm{CO}_{2}$ neutralized 1 ton of fertilizer (approximate) for 3 months

1 ton of fertilizer $=1$ ton of $\mathrm{CO}_{2}$ neutralized

\subsubsection{5 $\mathrm{CO}_{2}$ Neutralized due to Green Vegetation}

This depends on girth of various trees at the campus as follows which compares well with observations of Dr I.K Bhatt at the NIT, Hamirpur Campus.

Table 4

\begin{tabular}{|l|l|l|l|}
\hline $\begin{array}{l}\text { Type of } \\
\text { trees }\end{array}$ & $\begin{array}{l}\text { No of } \\
\text { trees }\end{array}$ & $\begin{array}{l}\mathrm{Kg} \text { of } \mathrm{CO}_{2} \\
\text { neutralized }\end{array}$ & $\begin{array}{l}\mathrm{Kg} \text { of } \mathrm{CO}_{2} \\
\text { neutralized per } \\
\text { year }\end{array}$ \\
\hline Teak & 700 & 705 & 493500 \\
\hline Silver oak & 700 & 650 & 455000 \\
\hline Mango & 200 & 700 & 140000 \\
\hline Pongemia & 500 & 800 & 400000 \\
\hline Neem & 300 & 600 & 180000 \\
\hline $\begin{array}{l}\text { Ficus } \\
\text { Religiosa }\end{array}$ & 50 & 700 & 35000 \\
\hline Gulmohr & 32 & 300 & 9600 \\
\hline Camel foot & 250 & 250 & 62500 \\
\hline Tecoma & 500 & 250 & 125000 \\
\hline Avalanda & 300 & 250 & 75000 \\
\hline Bottlebrush & 305 & 250 & 76250 \\
\hline
\end{tabular}

\begin{tabular}{|l|l|l|l|}
\hline $\begin{array}{l}\text { Pride of } \\
\text { india }\end{array}$ & 200 & 300 & 60000 \\
\hline Eucalyptus & 50 & 150 & 7500 \\
\hline Ccycas & 5 & 100 & 50 \\
\hline $\begin{array}{l}\text { Jumbulena } \\
\text { Indica }\end{array}$ & 50 & 500 & 25000 \\
\hline Guava & 100 & 150 & 15000 \\
\hline $\begin{array}{l}\text { Custard } \\
\text { apple }\end{array}$ & 20 & 100 & 2000 \\
\hline Bamboo & 150 & 350 & 52500 \\
\hline \multicolumn{4}{|c|}{ Total $=\mathbf{2 2 1 4 3 5 0} \mathbf{~ k g}$} \\
\hline
\end{tabular}

Total $\mathrm{CO}_{2}$ neutralized due to green vegetation $=2214.350$ tons of $\mathrm{CO}_{2}$ neutralized per year.

\subsubsection{Rain Water Harvesting Programme}

The 52 acre green campus gives facility for using trees as recharging points and only $20 \%$ of the area is paved surface. Also the roof tops collect the rain water and passes through a filter to be collected in a leaching rain water pool with disjointed mortar rings using dry joints. This facility near the borewells keep the drawdown curve at higher elevations during summer season.

Total $\mathrm{CO}_{2}$ Neutralized in $\mathrm{AMCEC}=2338.94$ tons of $\mathrm{CO}_{2}$ per Year

\section{CONCLUSION}

Total CFP contribution $\left(\mathrm{CO}_{2}\right.$ per year $)=1937.72$ tons of $\mathrm{CO}_{2}$

Total $\mathrm{CO}_{2}$ neutralized in AMCEC per year $=2338.94$ tons of $\mathrm{CO}_{2}$

401.22 tons of $\mathrm{CO}_{2}$ can be used for Extra CFP in future

AMCEC Campus is thriving towards Carbon Neutrality as a commitment from the Management towards mitigation of Global Climate Change in a miniscule effort.

Table 3

\begin{tabular}{|c|c|c|c|c|c|c|c|c|c|}
\hline $\begin{array}{l}\text { Type of } \\
\text { transpo } \\
\text { rtation }\end{array}$ & $\begin{array}{l}\text { Types } \\
\text { of fuel } \\
\text { used } \\
\text { petrol }\end{array}$ & $\begin{array}{l}\text { Mileage } \\
\mathrm{Km} / \mathrm{ltr}\end{array}$ & $\begin{array}{l}\text { Distance } \\
\text { travelled } \\
\text { per day } \\
(\mathrm{Km})\end{array}$ & $\begin{array}{l}\text { Distance } \\
\text { travelled } \\
\text { per year } \\
(\mathrm{Km})\end{array}$ & $\begin{array}{l}\text { Total no } \\
\text { of } \\
\text { vehicles } \\
\text { (Number } \\
\text { ) }\end{array}$ & $\begin{array}{l}\text { Petrol/diesel } \\
\text { Consumed/year } \\
\text { (Ltr) }\end{array}$ & $\begin{array}{l}\text { Emissio } \\
\mathrm{n} \quad \text { of } \\
\mathrm{CO}_{2} / \mathrm{ltr} \\
\text { of Petrol } \\
\text { in } \mathrm{Kg}\end{array}$ & $\begin{array}{l}\text { Emissio } \\
\mathrm{n} \text { of } \\
\mathrm{CO}_{2} / \text { litr } \\
\text { of diesel } \\
\text { in } \mathrm{kg}\end{array}$ & $\begin{array}{l}\text { Total } \\
\text { Emission } \\
\text { of } \mathrm{CO}_{2} \text { in } \\
\text { tons }\end{array}$ \\
\hline Bus & Diesel & $4 \mathrm{~km}$ & 30 & $30 \times 180$ & 2 & $(30 * 180 * 2) / 4=2700$ & & 2.68 & 7.236 \\
\hline Bus & Diesel & $7 \mathrm{~km}$ & 50 & 9000 & 4 & $(9000 * 4) / 7=5140.28$ & & 2.68 & 96.48 \\
\hline Car & Petrol & $12 \mathrm{~km}$ & 25 & $\begin{array}{lr}25 & x \\
180=4300\end{array}$ & 20 & $(4300 * 20) / 12=7500$ & 2.31 & & 17.32 \\
\hline Bike & Petrol & $50 \mathrm{~km}$ & 50 & 50 & 62 & $558000 / 50=11160$ & 2.31 & & 25.77 \\
\hline
\end{tabular}




\section{REFERENCES}

[1] Charles E. Button "Towards carbon neutrality and environmental sustainability at CCSU" International Journal of Sustainability in Higher Education Vol. 10 No. 3, 2009 pp. 279-286 (references)

[2] Ayça Tokuç, and Gülden Köktürk "Carbon Neutrality in University Campuses, Recent Advances in Environmental Sciences and Financial Development, ISBN: 978-1-61804-255-2.

[3] Baumert et al., 2005 U.S. Higher Education and Global Climate Change. 